\title{
Heavy Metals and 2,4-Dinitrophenol Impact on Some Physiological and Biochemical Parameters in Capsicum Species
}

\author{
Elena Todirascu-Ciornea ${ }^{1}$ \\ https://orcid.org/0000-0002-1478-5529
}

\author{
Gabriela Dumitru $^{1^{*}}$ \\ https://orcid.org/0000-0003-2074-1394
}

${ }^{1}$ Alexandru Ioan Cuza University of lasi, Faculty of Biology, Department of Biology, Carol I, lasi, Romania.

Received: 2018.03.02; Accepted: 2019.06.22.

* Correspondence: gabriela.dumitru@uaic.ro; Tel.: +40-0747081489; Fax: +40-0232201472 (G.D)

\section{HIGHLIGHTS}

- DNP and heavy metals' salts affected viability of Capsicum species.

- The activity of antioxidant enzymes varied significantly with the applied treatment.

- The presence of pesticides and heavy metals in the soil represents a major risk for the environment.

\begin{abstract}
The accumulation of heavy metals and of pesticides in the soil have a negative impact on Capsicum chinense var. Aji Mochero and Capsicum baccatum var. pendulum Bishop's Crown species, the present work highlighting the exerted influence on the superoxid-dismutase activity, catalase and peroxidase - as enzymes implied in the removal of $\mathrm{H}_{2} \mathrm{O}_{2}$, of $\mathrm{O}^{2-}$ radical and of ion $\mathrm{HO}^{-}$that have devastating effects on the vegetable cell, on the Krebs cycle's dehydrogenases - as main way to produce energy, respectively of the chlorophyll $a, b$ and carotenes - as photoassimilatory pigments, but also as biologic antioxidants.
\end{abstract}

Keywords: dinitrophenol; heavy metals; Capsicum; oxidative stress.

\section{INTRODUCTION}

The presence in the environment of the pesticides and of the different heavy metals turns on serious problems due to their toxicity significantly high and to the fact that vegetable organisms have the capacity to absorb from the soil these substances through roots and from the air, with the help of foliar apparatus, from where there are translocated at the level of the hole organism and from here on appears the food chain, representing an enormous risk for human's health and for animals [1].The specialty literature indicates the ecological 
risk's potential of peppers contamination with $\mathrm{Fe}, \mathrm{Cd}, \mathrm{Pb}$ and $\mathrm{Ni}$, risk as higher as in the soil and the aerial parts of the Capscium gender there is a Mn deficit [2].

The Capsicum species gender contain a large variety of nutritional compounds, also active pharmacologic metabolites [3], being frequently used for different digestive problems, circulatory, neuropathy associated with diabetes mellitus and HIV, rheumatoid disease, sinusitis and different migraines [4].

The present work aimed to evaluate the biochemical and physiological answer of Capsicum chinense var. Aji Mochero and Capsicum baccatum var. pendulum Bishop's Crown, species, cropped in lab conditions, at the action of some pesticides and salts of heavy metals taking a common sense view of superoxid-dismutase activity (SOD), catalase (CAT), peroxidase (POX), Krebs cycle's dehydrogenases (izocitrat-dehydrogenase - IDH, ketoglutarat-dehydrogenase $-\mathrm{KDH}$, succinat-dehydrogenase $-\mathrm{SDH}$ and malate-dehydrogenase $-\mathrm{MDH}$ ) and of the content of chlorophyllien and carotenoidic pigments.

\section{MATERIAL AND METHODS}

\section{Plant material}

The researches were done on two types belonging to Capsicum gender namely Capsicum chinense var. Aji Mochero and Capsicum baccatum var. pendulum Bishop's Crown cropped in lab conditions. Thus, the seeds were cropped in vases of $25 \mathrm{~cm}$ diameter, at $3 \mathrm{~cm}$ deepness in the soil and moistened, at three days, during five weeks, with constantly volume of distilled water, obtained through a MilliQ $(18,2 \Omega)$ system. Subsequently was resorted to the apply of different types of treatments $\left[\left(\mathrm{CH}_{3} \mathrm{COO}\right)_{2} \mathrm{~Pb}, \mathrm{FeSO}_{4}, \mathrm{SnCl}_{2}\right]$, the solutions used being prepared so that the final concentration of the metal to be of $0.005 \mathrm{M}$. In parallel we resorted at the obtaining of some samples treated with 2,4 - dinitrophenol (DNP), in concentration of $0.005 \mathrm{M}$, substance that enters in composition of different pesticides, weed killers, fungicides, ovicides, acaricides etc. and thus used more frequently in the last years, in the modern agricultural practices. For each type of treatment in part were obtained three parallel plots of peppers, the experimental results representing the average of these repetitions \pm the standard deviation. The harvest of the samples was done at two months after the beginning of applying treatments.

\section{Reagents and instruments}

Were used: TRIS- $\mathrm{HCl} 0.1 \mathrm{M}$ with $\mathrm{pH} 7.8$ buffer solution which contain $1 \mathrm{mmol}$ dithiothreitol and $1 \mathrm{mmol}$ EDTA; buffer solution potassium phosphate $0.067 \mathrm{M}$ with $\mathrm{pH} 7.8$, $0.01 \mathrm{M}$ with $\mathrm{pH} 7.0$ and, respectively, $0.4 \mathrm{M}$ with $\mathrm{pH} 5.9$; EDTA disodic $0.01 \mathrm{M}$ with $\mathrm{pH} 7.8$; Nitro Blue Tetrazolium (NBT) $1.5 \mathrm{mM}$ solution; riboflavine solution $0.12 \mathrm{mM}$; potassium bicromate $5 \%$ in glacial acetic acid ; o-dianisidine $1 \%$ in ethylic alcohol $96 \%$; $\mathrm{H}_{2} \mathrm{SO}_{4} 50 \%$; $\mathrm{H}_{2} \mathrm{O}_{2}$; acetone; Coomassie Briliant Blue $\mathrm{G}_{250}$.

All the reagents used were of high analytic purity, and the solutions were prepared in distilled water obtained in a MilliQ system. The extinctions determination was done with a UV-VIS Shimadzu 1700 spectrophotometer, in quartz cuves of $1 \mathrm{~cm}$, towards a control of the reagents, specific to each method in part.

\section{Principle of the methods}

SOD (superoxide: superoxid - oxidoreductase, EC 1.15.1.1) catalyze the dismutation of the free radical superoxide in $\mathrm{O}_{2}$ and $\mathrm{H}_{2} \mathrm{O}_{2}$, its activity being determined on the enzyme's capacity to inhibit the NBT reduction of superoxide radicals generated in the reaction medium through riboflavin's photoreduction. The inhibition degree produced by the enzyme, in standard conditions, was estimated through the determination of samples' and controls' extinctions at $560 \mathrm{~nm}$, towards the distilled water [5].

CAT $\left(\mathrm{H}_{2} \mathrm{O}_{2}: \mathrm{H}_{2} \mathrm{O}_{2}\right.$ - oxidoreductase, EC 1.11.1.6) is implied in the detoxification of the hydrogen peroxide, species oxygen reactive which results, after different ordinary and 
pathologic processes, under the SOD action and of the different oxidases. The activity of this enzyme was estimated by Synha method, colorimetric determination based of the chromic acetate obtained by reaction of the potassium bicromate's reduction in the acid medium by the distilled water left-over undissolved after the enzyme's inactivation, at $570 \mathrm{~nm}$ [6].

POX (donor: hydrogen peroxide - oxidoreductase, EC 1.11.1.7) performs a significant role in the oxido-reducing processes correlated with the plants respiration, the enzyme being able to oxidize, in $\mathrm{H}_{2} \mathrm{O}_{2}$ presence a big number of substratum like fenols of pirocatechine's type, pirogalol and galic acid, the aromatic amines such as benzidine and p-phenilendiamine, but also substances slightly oxidable of vitamin $\mathrm{C}$ and glutathione type. The method of this peroxidase's activity dosage is based on measuring the oxidation product color's intensity of o-dianisidine with $\mathrm{H}_{2} \mathrm{O}_{2}$ help, the formed product having a maximum absorption at the 540 $\mathrm{nm}$ wavelength [5].

The concentration of total soluble proteins was determined through Bradford method which is based on the observation that, in acid medium, the Coomassie Brilian Blue $\mathrm{G}_{250}$ reagent reactions with radicals of arginine, histidine, lizine, tirozine, triptophane and phenilalanine from the proteins' structure, the formed complex having a maximum of absorption at $595 \mathrm{~nm}[7]$.

The content of chlorophyllien pigments which represent the prosthetic groups of the chlorophylls and those carotenoidic was estimated on spectrophotometrical way, after the extraction with acetone, at 663, 645 and $472 \mathrm{~nm}$ wavelengths [8].

\section{Statistics}

The statistic processing of the experimental data obtained was realized with the SPSS20 program (Statistical Package for the Social Sciences, Chicago, Illinois) and Microsoft Excel (the t-Student test), being considered significant at values of $p$ littler than 0.05 . The data were expressed as medium values on each plot \pm standard deviation.

\section{RESULTS AND DISCUSSION}

The environment's pollution with heavy metals, as a result of different industrial activities, but also with a series of pesticides, fungicides, ovicides etc. used in the agricultural maintenance techniques, has a negative impact on the human's health and animals' [9-12]. Although the negative effects due to different toxic substances are knew long time ago, they continue to be used on large scale in the whole world, the pollution with heavy metals and pesticides being a major problem in lots of geographical areas [13]. The specialty literature signalize the importance of the interactions between the synergic circumstances and antagonists based, especially, on the individual effects of each pollutant in part, imposing the necessity to know the impact produced by the combinations of metallic ions in different concentrations at the plants' level [14]. Furthermore, the development and the productivity of plants are profoundly affected by the environment's pollution, the different biotic and abiotic factors producing major imbalances at the cellular level, the resulted stress being accompanied by the storage of an enhanced quantity of reactive oxygen species [15, 16].

The apply of DNP treatments and salts of heavy metals at the Capsicum chinense var. Aji Mochero species had different consequences on the activity of SOD, CAT and POX, in the sense that, for the most part, leaded to significant increases of the activities of these oxido-reducing enzymes, strongly correlated with the concentration of the formed free radicals (Figure 1 ). Thus, if at the control, the SOD activity reach a valoric threshold equal with $50.221 \pm 1.265 \mathrm{EU} / \mu \mathrm{g}$ protein, at the experimented variants treated with DNP and $\mathrm{SnCl}_{2}$ solutions the enzyme registers maximal values of approximately $63 \mathrm{EU} / \mu \mathrm{g}$ protein, while the plots treated with $\left(\mathrm{CH}_{3} \mathrm{COO}\right)_{2} \mathrm{~Pb}$ and $\mathrm{FeSO}_{4}$ remark their self by an inhibition degree more diminished of the NBT reduction by the superoxide radicals generated in the reaction medium through riboflavine's photoreduction $(36.426 \pm 1.009 \mathrm{EU} / \mu \mathrm{g}$ protein, respectively $41.221 \pm 1.156 \mathrm{EU} / \mu \mathrm{g}$ protein). An enzymatic unity is defined as being equal with amount of enzyme required to cause $50 \%$ inhibition of the NBT reduction. 
The superoxide radicals are comparatively less toxic but are highly reactive and leads to a series of chain reactions thus generating very toxic radicals via Haber Weiss reaction [17]. The specialty literature signalize the fact that the metals can be essential and non-essential for the plants' growth, with different answers in function of the concentration for both classes, some of them having a crucial role for the vegetable organisms' metabolism, while others, even at reduced concentrations, produce imbalances at the level of biochemical and physiological processes with repercussions on the plants' growth and productivity [18-20]. On the other hand, ROS and $\mathrm{H}_{2} \mathrm{O}_{2}$ especially, are considered essential compounds of the transgoing signal used by the plants to answer to the developmental and environmental cues [21], SOD being the first defense line in the antioxidant defensive [22].

The CAT activity oscillates in largely limits, the medium value being decelated at the control plot (18.312 $\pm 0.659 \mathrm{EU} / \mu \mathrm{g}$ protein), and the maximum in the case of the treatment with $\left(\mathrm{CH}_{3} \mathrm{COO}\right){ }_{2} \mathrm{~Pb}(44,802 \pm 1.025 \mathrm{EU} / \mu \mathrm{g}$ protein) and DNP $(42.227 \pm 1.235 \mathrm{EU} / \mu \mathrm{g}$ protein), while POX lays out a maximum valoric threshold of $12.459 \pm 0.556 \mathrm{EU} / \mu \mathrm{g}$ protein in the case of the sample treated with DNP, followed by that one treated with $\mathrm{FeSO}_{4}(9.726 \pm 0.065$ $\mathrm{EU} / \mu \mathrm{g}$ protein) and $\left(\mathrm{CH}_{3} \mathrm{COO}\right)_{2} \mathrm{~Pb}(7.565 \pm 0.12 \mathrm{EU} / \mu \mathrm{g}$ protein). To mention that a catalasic unity represents the enzyme quantity which decompose a micromole of $\mathrm{H}_{2} \mathrm{O}_{2}$ during 1 minute at $\mathrm{pH} 7.0$ and $20^{\circ} \mathrm{C}$ temperature, while a peroxidase unity corresponds to the enzyme's quantity which catalyze the decomposing of a micromole $\mathrm{H}_{2} \mathrm{O}_{2}$ in a minute in optimum conditions.

A series of researches demonstrated the phytotoxicity particularly high of the DNP which produce major imbalances of the metabolic reactions as a consequence of the free oxygen radicals' accumulation, the increase of oxidative stress' level determining implicitly the increase of oxido-reducing's activity [23, 24]. In the same time, the iron excess [25] and lead [26] in plants may lead to the leaves' necrosis as a sign of the oxidative stress' installment, the storage of the lead at cellular level having as non-specific visual symptoms, the inhibition of roots growth, the stagnation of plant growth, or even the cellular death [27, 28].

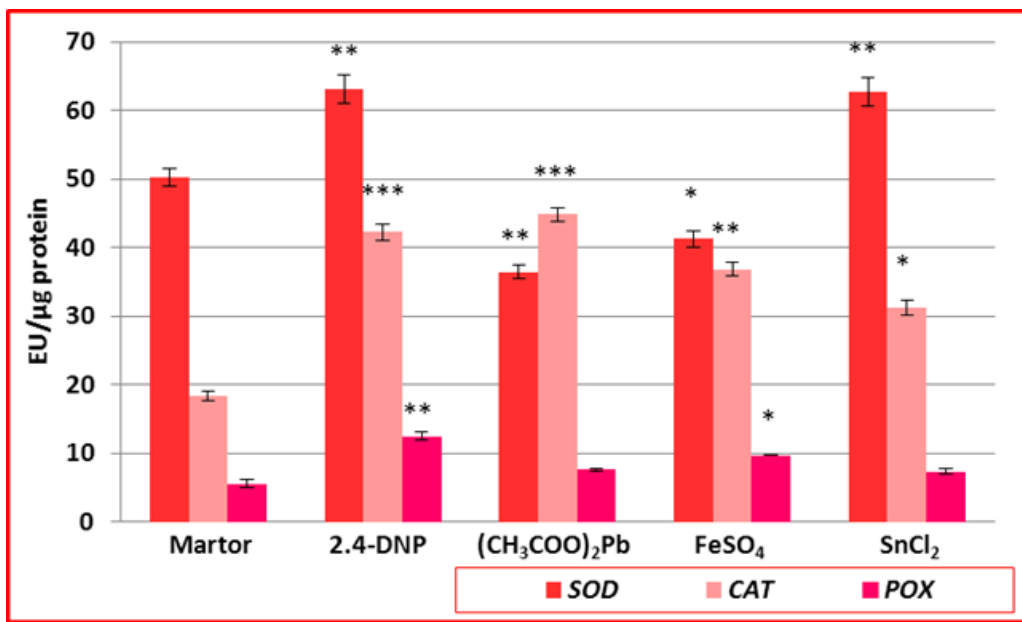

Figure 1. SOD, CAT, POX activity at Capsicum chinense var. Aji Mochero species ( ${ }^{*} p<0.05-$ less significant; ${ }^{* *} p<0.01-$ significant; ${ }^{* * *} p<0.001$ - very significant).

In what concerns the Capsicum baccatum var. pendulum Bishop's Crown species, the SOD, CAT, POX activity present a similar manner of behavior, being unremarkable notable differences comparatively with Capsicum chinense var. Aji Mochero species (Figure 2). Thus, at SOD, the activity presents largely limits of variation, in the sense that the apply of DNP treatment leaded to an intensify of the superoxide radicals' mobilization comparatively with the reference plot $(62.892 \pm 1.965 \mathrm{EU} / \mu \mathrm{g}$ protein towards $41.599 \pm 1.126 \mathrm{EU} / \mu \mathrm{g}$ protein), while, also this time, $\left(\mathrm{CH}_{3} \mathrm{COO}\right)_{2} \mathrm{~Pb}$ inhibited the NBT reduction, but in a diminished percent $(36.693 \pm 1.11 \mathrm{EU} / \mathrm{\mu g}$ protein). Besides, the scientific literature highlights the decreasing of some enzymes' activity at different lead concentrations in the environment [26]. 
The CAT activity was intensive stimulated by DNP used during the experiment, the enzyme registering a medium value of approximately three times higher comparatively with the moistened plot with water $(46.465 \pm 1.023 \mathrm{EU} / \mu \mathrm{g}$ protein, respectively $16.268 \pm 0.569$ $\mathrm{EU} / \mu \mathrm{g}$ protein), while $\mathrm{SnCl}_{2}$ and $\mathrm{FeSO}_{4}$ were highlighted their self by moderate effects, the enzyme laying out values of approximately $25 \mathrm{EU} / \mu \mathrm{g}$ protein.

POX is an enzyme implied in multiple cellular processes like the polymerization of aromatic monomers, lignification, the cells' elongation, auxines' catabolism, the phenolic oxidation and the defense against the biotic and abiotic stress represented by different pathogens [29-32].

Also in this case, the apply of the DNP treatment had as consequence the increase of POX activity $(14.435 \pm 0.653 \mathrm{EU} / \mu \mathrm{g}$ protein in the treated plot comparatively with $9.725 \pm 0.336 \mathrm{EU} / \mu \mathrm{g}$ protein at the reference plot), demonstrating, once again, the high toxicity of this agent. The $\left(\mathrm{CH}_{3} \mathrm{COO}\right)_{2} \mathrm{~Pb}$ and $\mathrm{FeSO}_{4}$ solutions had approximately the same impact in what concerns the storage of ROS, the enzyme laying out the medium value of 10.25 EU/ $\mu$ g protein, while the treatment with $\mathrm{SnCl}_{2}$ was remarked through an inhibition of the enzymatic activity, the medium value registered being with approximately two unities littler by comparison with the plot treated with water ( $7.324 \pm 0.62 \mathrm{EU} / \mu \mathrm{g}$ protein).

In explaining the results we must take into account that the modify of the activity of this oxidoreductase oscillates in strong connection with the plants' age and the duration of the treatment administered [33], the specialty literature signalizing a capacity of peroxidation different function of the stage in which there are the processes of cellular differentiation and development of the tissues [34-36].

The statistical analyze regarding the activity of some enzymes implied in the oxidative stress highlighted, at both species, the existence of some significant and strongly significant differences between the reference plot and the samples treated with DNP and $\left(\mathrm{CH}_{3} \mathrm{COO}\right)_{2} \mathrm{~Pb}$ in what concerns the SOD and CAT activity $(0.01<\mathrm{p}<0.001)$.

The experimental data obtained concord with those from the scientific literature which signalize the stimulatory influence that $\mathrm{FeSO}_{4}$ exerts, respectively the $\mathrm{Fe}$ ion from different other salts, on the POX's activity [37, 38]. Other studies highlight the iron's importance in quality of main cofactor of many other antioxidant enzymes, this element being able to function as a prooxidant forasmuch catalyzes the free radicals by Fenton reaction [39], its direct influence on CAT and SOD activity depending on its concentration in the environment, the increase activity of SOD being able to appear as a result of the superoxide radicals' storage at the leaves' level, which or is suffering of iron deficit [40], or they are having a redundancy of this metallic ion [41]. On the other hand, comparatively with the control plot, the $\mathrm{Pb}$ treatment may cause the significant increase of CAT and POX activity from the foliar tissue, in parallel with the reduction of increasing rate of the root and of the stem, but also of the chlorophyllien pigments content [42].

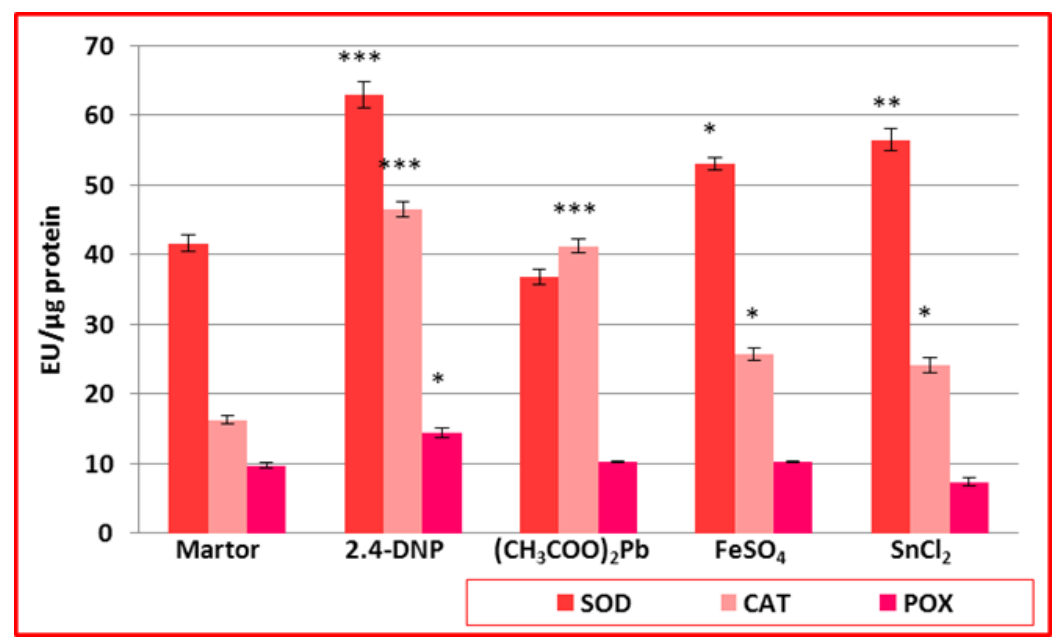

Figure 2. SOD, CAT, POX activity at Capsicum baccatum var. pendulum Bishop's Crown species ( ${ }^{*} \mathrm{p}$ $<0.05$ - less significant; ${ }^{* *} p<0.01-$ significant; ${ }^{* * *} p<0.001$ - very significant). 
In the same time, was demonstrated the fact that the CAT activity, in the lead presence, is lower in roots and more significantly at the stem's level and at the foliar device, and it depends of the heavy metal's concentration, up to a certain concentration, considered moderate-toxic, the enzymatic activity increasing significantly, the plants presenting high tolerance towards this ion, while, at higher concentrations, strongly toxic, the activity decreases drastically, and the effect on the vegetable organisms is devastating [43].

Another purpose of our study was the evaluation of Krebs cycle's dehydrogenases' activity under the influence of the above treatments. At the control plots, in the case of Capsicum chinense var. Aji Mochero species (Figure 3), the dehydrogenasic activity varied between $10.956 \pm 0.35 \mu \mathrm{g}$ formazan $/ \mathrm{g}$ fresh tissue at IDH and $5.525 \pm 0.3 \mu \mathrm{g}$ formazan $/ \mathrm{g}$ fresh tissue at $\mathrm{KDH}$, while, the different treatments applied had effects more or less significant and different from an enzyme to another. Thus, IDH registered the maximum valoric threshold at the plot treated with $\left(\mathrm{CH}_{3} \mathrm{COO}\right)_{2} \mathrm{~Pb}(24.841 \pm 0.3 \mu \mathrm{g}$ formazan $/ \mathrm{g}$ fresh tissue), followed by 2,4 - DNP (19.282 $\pm 0.08 \mu \mathrm{g}$ formazan/g fresh tissue) and $\mathrm{FeSO}_{4}(15.349 \pm 0.55 \mu \mathrm{g}$ formazan $/ \mathrm{g}$ fresh tissue), while $\mathrm{KDH}$ and $\mathrm{SDH}$ were significantly stimulated by $\mathrm{SnCl}_{2}(8.516 \pm 0.025 \mu \mathrm{g}$ formazan/g fresh tissue) and $\mathrm{FeSO}_{4}(9.223 \pm 0.45 \mu \mathrm{g}$ formazan $/ \mathrm{g}$ fresh tissue). The malate's mobilization takes place with a littler rate, being ascertained medium values net inferior to control in the case of $\mathrm{DNP}, \mathrm{FeSO}_{4}$ and $\mathrm{SnCl}_{2}$, at the variant treated with $\mathrm{Pb}$ the enzyme reaching valoric levels comparative to the reference sample $(9.215 \pm 0.35 \mu \mathrm{g}$ formazan $/ \mathrm{g}$ fresh tissue).

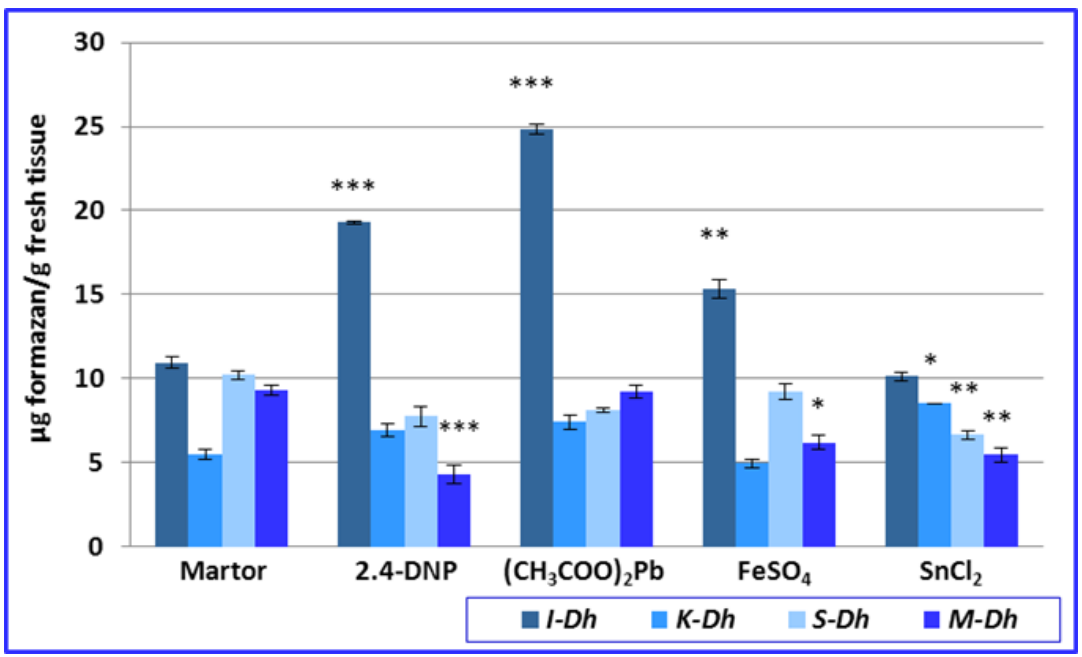

Figure 3. Krebs cycle dehydrogenases activity at Capsicum chinense var. Aji Mochero species $\left({ }^{*} p<0.05\right.$ - less significant; ${ }^{* *} p<0.01$ - significant; ${ }^{* *} p<0.001$ - very significant).

At Capsicum baccatum var. pendulum Bishop's Crown (Figure 4) can be observed medium values generally decreased, IDH laying out activities contained in the interval $6.942 \pm 0.25 \mu \mathrm{g}$ formazan $/ \mathrm{g}$ fresh tissue (in the case of applying treatment with $\mathrm{Pb}$ ) and $9.971 \pm 0.28 \mu \mathrm{g}$ formazan $/ \mathrm{g}$ fresh tissue at the reference sample, $\mathrm{FeSO}_{4}$ and $\mathrm{SnCl}_{2}$, inhibiting equally the activity of these oxidoreductase (approximately $7.5 \mu \mathrm{g}$ formazan $/ \mathrm{g}$ fresh tissue on each plot). The $\alpha$-ketoglutarate in succinil-CoA conversion takes place in a different manner in the studied plots, the $\mathrm{KDH}$ activity reaching the medium value of $8.231 \pm 0.2 \mu \mathrm{g}$ formazan $/ \mathrm{g}$ fresh tissue in the case $\mathrm{Pb}$ acetate, $9.326 \pm 0.35 \mu \mathrm{g}$ formazan $/ \mathrm{g}$ fresh tissue at $\mathrm{FeSO}_{4}$, approximately $10 \mu \mathrm{g}$ formazan/g fresh tissue at the applying of $\mathrm{DNP}$ and $\mathrm{SnCl}_{2}$ solutions and $15.693 \pm 0.25 \mu \mathrm{g}$ formazan/g fresh tissue at the control plot. SDH and MDH were stimulated by the agents used, maximal values being met in the case of the variants with $\mathrm{SnCl}_{2}(9.526 \pm 0.25 \mu \mathrm{g}$ formazan/g fresh tissue for SDH and $6.412 \pm 0.35 \mu \mathrm{g}$ formazan $/ \mathrm{g}$ fresh tissue for $\mathrm{MDH}$ ). It must be underlined the high importance in evaluating the oxidoreductases' activity of the biologic material's harvest moment and the stage in which there is overtook the Krebs cycle, the specialty literature underlying the IDH implying in the cellular senescent process, the enzyme having a direct role in storing with NADH necessary for the antioxidant protection of the mitochondria [44]. On the other hand, it is to remember 
the fact that, in addition to the formed compounds in the Krebs cycle and degraded in a subsequently stage of this one, the substratum specific to the enzymes in the case, may derive also on other anabolic or catabolic ways [45].

The statistical processing of the results regarding the dehydrogenases' activity's Krebs cycle, points the existence of some differences strongly significant $(p<0.001)$ between the reference samples and that treated with $\mathrm{DNP}$ and $\mathrm{Pb}$ acetate at the Capsicum chinense var. Aji Mochero species (in the IDH's case), respectively significant $(p<0.01)$ and strongly significant $(p<0.001)$ in the case of applying $\mathrm{Pb}, \mathrm{Fe}$ and $\mathrm{Sn}$, on the activity $\mathrm{KDH}$ and $\mathrm{SDH}$, at the Capsicum baccatum var. pendulum Bishop's Crown species.

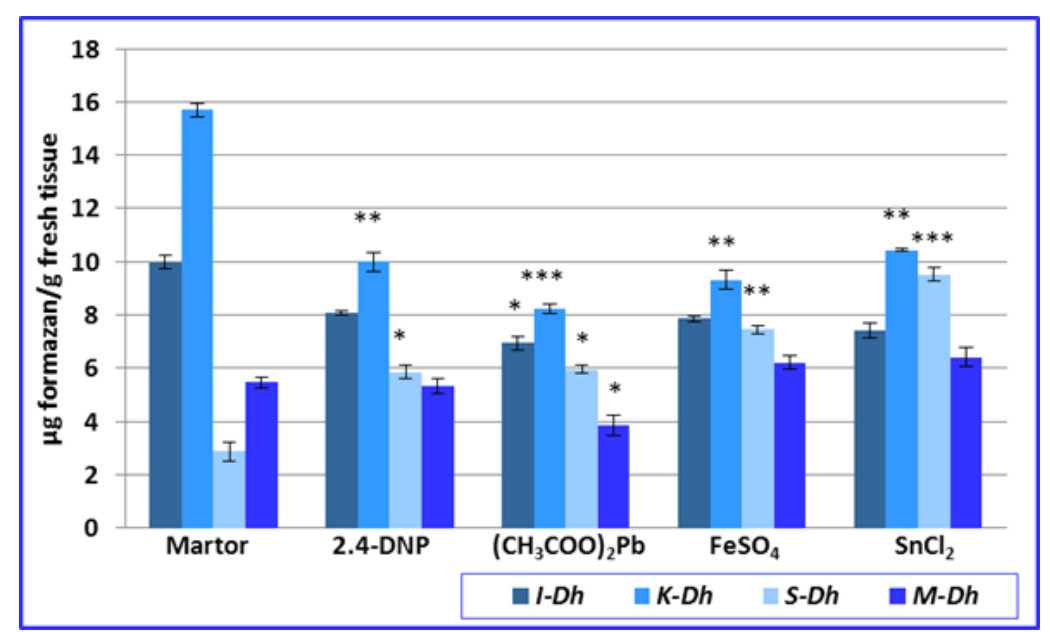

Figure 4. Krebs cycle dehydrogenase activity at Capsicum baccatum var. pendulum Bishop's Crown ( ${ }^{*} p<0.05$ - less significant; ${ }^{* *} p<0.01-$ significant; ${ }^{* *} p<0.001-$ very significant).

Being known the fact that the heavy metals have a strong impact on the enzymes' activity implied in the antioxidant defensive on the one hand, but also on the photosynthesis' and sweating rate, respectively on the chlorophyll and carotenes content, on the other hand [46], in a last series of experiments we had recourse to evaluating the physiologic answer of the two species of peppers at the agents' action input in the growing environment taking a common sense view of the concentration of chlorophyllien and carotenoidic pigments. Besides, the answer and the accommodation of the plants to continuous fluctuations of the environment's conditions are translated by physiological and biochemical modifications to survive in different stress conditions [15].

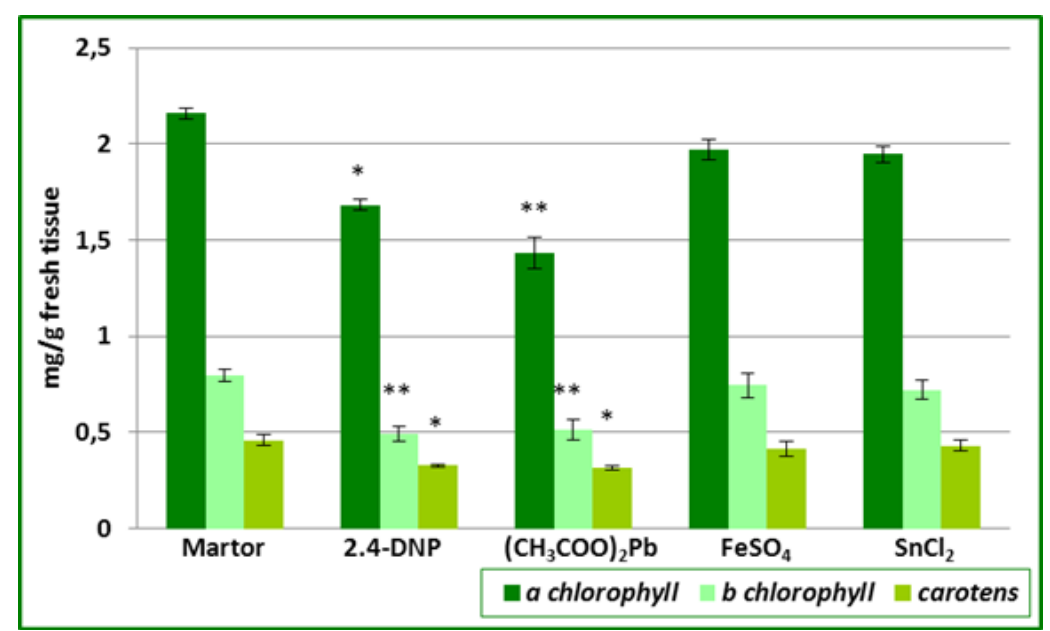

Figure 5. Chlorophylliens and carotenoides pigments concentration at Capsicum chinense var. Aji Mochero species $\left({ }^{*} p<0.05\right.$ - less significant; ${ }^{* \star} p<0.01$ - significant; ${ }^{* * *} p<0.001$ - very significant).

In what concerns the chlorophyll a, photosynthetic pigment which helps the plants to procure itself energy from the light, we can ascertain a slightly diminution of the content comparatively with the reference plot $(2.158 \pm 0.025 \mathrm{mg} / \mathrm{g}$ fresh tissue), the medium values 
decelated being of $1.432 \pm 0.08 \mathrm{mg} / \mathrm{g}$ fresh tissue at the variant containing $\mathrm{Pb}$ acetate, $1.683 \pm 0.03 \mathrm{mg} / \mathrm{g}$ fresh tissue at that with DNP and approximately $1.95 \mathrm{mg} / \mathrm{g}$ fresh tissue at the plots treated with Sn and Fe (Figure 5). By comparison, the chlorophyll b and the carotenoids lay out values much more decreased, being ascertained, nevertheless, significant differences between the control plot and the experimental variants in which were applied solutions of DNP and $\left(\mathrm{CH}_{3} \mathrm{COO}\right)_{2} \mathrm{~Pb}[0.796 \pm 0,03 \mathrm{mg} / \mathrm{g}$ fresh tissue - control, $0.492 \pm 0.04 \mathrm{mg} / \mathrm{g}$ fresh tissue $-\mathrm{DNP}$ and $0.512 \pm 0.055 \mathrm{mg} / \mathrm{g}$ fresh tissue $-\left(\mathrm{CH}_{3} \mathrm{COO}\right)_{2} \mathrm{~Pb}$ for the chlorophyll b, respectively $0.46 \pm 0.03 \mathrm{mg} / \mathrm{g}$ fresh tissue - reference carotenes and approximately $0.32 \mathrm{mg} / \mathrm{g}$ fresh tissue at DNP and $\left.\left(\mathrm{CH}_{3} \mathrm{COO}\right)_{2} \mathrm{~Pb}\right]$.

At the Capsicum baccatum var. pendulum Bishop's Crown species the situation is slightly different, in the sense that, at the plots treated, there are ascertained valoric thresholds slightly superior of the chlorophyll a and b comparatively with the control sample, excepting the variant with $\mathrm{FeSO}_{4}$, where the decelated concentration was under the reference threshold $(1.515 \pm 0.0035 \mathrm{mg} / \mathrm{g}$ fresh tissue and $1.407 \pm 0.055 \mathrm{mg} / \mathrm{g}$ fresh tissue chlorophyll a, respectively $0.634 \pm 0.03 \mathrm{mg} / \mathrm{g}$ fresh tissue and $0.58 \pm 0.04 \mathrm{mg} / \mathrm{g}$ fresh tissue chlorophyll b). The specialty literature highlights the influence that exerts the different concentrations of the pesticides [10,47] and of the heavy metals [48-50] on the assimilatory pigments content. Different studies [51-53] signalize the reducing of the chlorophyll's $a$ and $b$ level and of the carotenes under the influence of $\mathrm{Fe}$ and $\mathrm{Pb}$ ion's which can be associated with the absorption and the deficitary distribution of the essential nutrients, which has as consequence the growing process' perturbation of the plants.

The carotenes content, as biologic antioxidants and key factors in reducing the diseases incidence, it's remarked through medium levels slightly decreased, highlighting values of the order of $0.371 \pm 0.01 \mathrm{mg} / \mathrm{g}$ fresh tissue at the variant with $\mathrm{DNP}, 0.337 \pm 0.04$ $\mathrm{mg} / \mathrm{g}$ fresh tissue at that with $\mathrm{FeSO}_{4}$ and $0.357 \pm 0.03 \mathrm{mg} / \mathrm{g}$ fresh tissue at the plot grew on the environment containing $\mathrm{SnCl}_{2}$. Significant differences between the control plot and the variant with $\mathrm{Pb}$ were remarked after applying the test of statistical signification Student, the carotenes' concentration in the two plots being of $0.426 \pm 0.03 \mathrm{mg} / \mathrm{g}$ fresh tissue, respectively $0.256 \pm 0.04 \mathrm{mg} / \mathrm{g}$ fresh tissue (Figure 6).

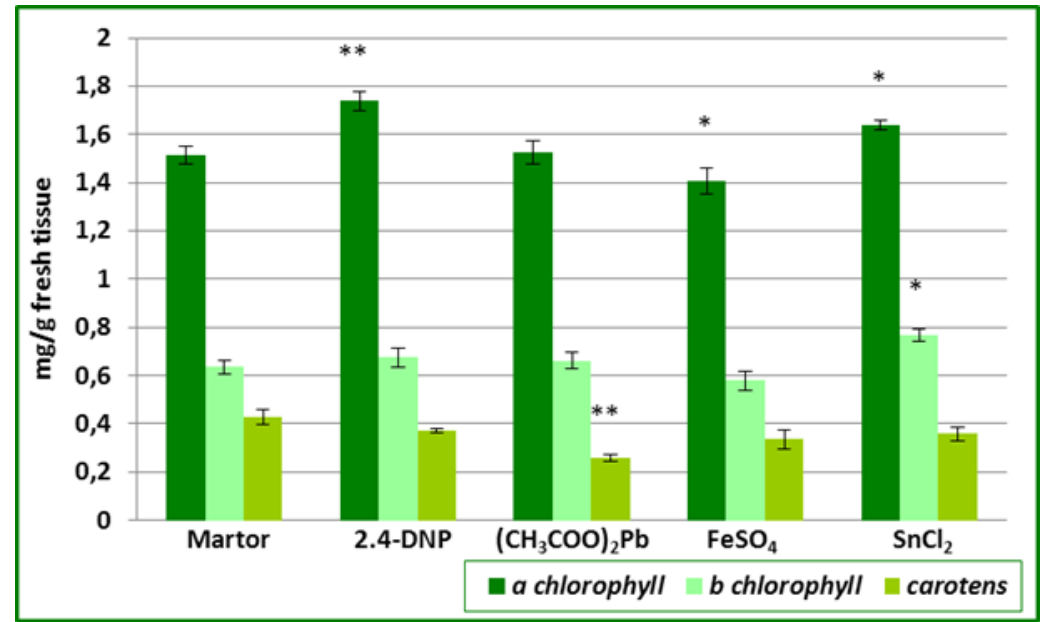

Figure 6. Chlorophylliens and carotenoides pigments concentration at Capsicum baccatum var. pendulum Bishop's Crown species ( ${ }^{*} p<0.05$ - less significant; ${ }^{* *} p<0.01$ - significant; ${ }^{* *} p<0.001-$ very significant).

The carotenes concentrations, according to recent studies [54-56], it's influenced by a series of factors like the presence of different biotic and abiotic factors in the environment, the genotype, the agronomic factors etc.

\section{CONCLUSION}

Our results demonstrate the impact deeply negative of the applying pesticides and heavy metals' salts on the Capsicum chinense var. Aji Mochero and Capsicum baccatum var. pendulum Bishop's Crown species' viability, the SOD, CAT, POX activity and Krebs 
cycle's dehydrogenases, as well as the concentration of chlorophyllien pigments and carotenoids being significantly influenced by the presence of the respective agents in the growth environment, strongly correlated with the level of oxidative stress generated by the quantity of ROS produced in the cell. Taken together, these results suggest the necessity of fixing some dosages rigorously determined by the pesticides and other agents with recognized phytotoxicity, with the aim of controlling the physiological and the biochemical answer of the plants at the storage of free oxygen radicals, the vegetable organisms having the capacity of adapting to the presence of heavy metals in soil, the tolerance degree of these ones being assured by the presence of enzymatic and non-enzymatic equipments.

Funding: This research received no external funding.

Conflicts of Interest: The authors declare no conflict of interest.

\section{REFERENCES}

1. Baba Ahmed A, Bouhadjera K. Assessment of metals accumulated in Durum wheat (Triticum durum Desf.), pepper (Capsicum annuum) and agricultural soils. Afr $J$ Agric Res. 2010;5(20):2795-800.

2. Baba-Ahmed A, Bouhadjera K. Seasonal variation in metal accumulation in pepper (Capsicum annuum) and soils. Middle-East Journal of Scientific Research. 2013;15(11): 521-7.

3. Nica-Badea D. Control of pungent active principles from indigenous peppers, by chromatographic techniques coupled with mass spectrometry, as a method of identifying and confirming the separated compounds. Rev Chim. 2016;67(1):92-5.

4. Geeta S, Goyal AK. Response of UV-B radiation on germination percentage, growth pattern and chlorophyll content at seedling stage of Capsicum anuum L. International Journal of Scientific and Reseach Publications. 2014; 4(8).

5. Cojocaru DC. Enzimologie practică. laşi: Editura Tehnopress; 2005. p. 153-155.

6. Artenie V, Ungureanu E, Negură A. Metode de investigare a metabolismului glucidic şi lipidic. laşi: Editura Pim; 2008. p. 100-110.

7. Cojocaru D, Toma O, Cojocaru SI, Ciornea E. Practicum de biochimia proteinelor şi acizilor nucleici. Iaşi: Editura Tehnopress; 2009. p. 146-150.

8. Căpraru G, Băra I. Cereale, pesticide, mutaţii - Efecte citogenetice şi fiziologice induse de tratamentul cu pesticide la orz, orzoaică şi secară. Iaşi: Editura Universităţii Alexandru Ioan Cuza; 2007. p. 62-63.

9. Waisberg M, Joseph P, Hale B, Beyersmann D. Molecular and cellular mechanisms of cadmium carcinogenesis. Toxicology. 2003;192:95-117.

10. Tiyagi SA, Ajaz S, Azam MF. Effect of some pesticides on plant growth, root nodulation and chlorophyll content of chickpea. Arch Agron Soil Sci. 2004;50:529-33.

11. Aktar W, Sengupta D, Chowdhury A. Impact of pesticides use in agriculture: their benefits and hazards. Interdiscip Toxicol. 2009;2(1):1-12.

12. Obuseng VC, Mookantsa BM, Okatch H, Mosepele K, Nelsontorto S. Extraction of pesticides from plants using solid phase microextraction and QuEChERS. Afr J Chem. 2013;66:183-8.

13. Lente I, Ofosu-Anim J, Brimah AK, Atiemo S. Heavy metal pollution of vegetable crops irrigated with wastewater 41 heavy metal pollution of vegetable crops irrigated with wastewater in Accra, Ghana. West African Journal of Applied Ecology. 2014;22(1):41-58.

14. Ting YP, Lawson F, Prince IG. Uptake of cadmium and zinc by alga Chlorella vulgaris: Multiion situation. Biotechnol Bioeng. 1991;37:445-55.

15. Alcázar R, Marco F, Cuevas JC, Patron M, Ferrando A, Carrasco P, Tiburcio AF, Altabella T. Involvement of polyamines in plant response to abiotic stress. Biotechnol Lett. 2006;28(23):1867-76.

16. John R, Ahmad P, Gadgil K, Sharma S. Effect of cadmium and lead on growth, biochemical parameters and uptake in Lemna polyrrhiza L. Plant Soil Environ. 2008;54(6):262-70.

17. Kumar R, Arora R, Mahajan J, Mahey S, Arora S. Polyphenols from cutch tree (Acacia catechu Willd.): normalize in vitro oxidative stress and exerts antiproliferative activity. Braz Arch Biol Technol. 2017;60:e17160728. doi:10.1590/1678-4324-2017160728. 
18. Hänsch R, Mendel RR. Physiological functions of mineral micronutrients ( $\mathrm{Cu}, \mathrm{Zn}, \mathrm{Mn}, \mathrm{Fe}, \mathrm{Ni}, \mathrm{Mo}$, B, Cl). Curr Opin Plant Biol. 2009;12:259-66.

19. Pilon M, Cohu CM, Ravet K, Abdel-Ghany SE, Gaymard F. Essential transition metal homeostasis in plants. Curr Opin Plant Biol. 2009;12: 47-57.

20. Lin YF, Aarts MGM. The molecular mechanism of zinc and cadmium stress response in plants. Cell Mol Life Sci. 2012;69:3187-206.

21. Cuypers A, Hendrix S, Amaral Dos Reis R, De Smet S, Deckers J, Gielen H, Jozefczak M, Loix $\mathrm{C}$, Vercampt $\mathrm{H}$, Vangronsveld J, Keunen $\mathrm{E}$. Hydrogen peroxide, signaling in disguise during metal phytotoxicity. Front Plant Sci. 2016;7:470.

22. De Oliveira MC, Ferreira Schoffen JP. Oxidative stress action in cellular aging. Braz Arch Biol Technol. 2010;53(6):1333-42.

23. Pintilie O, Andries C, Cosma A, Zaharia M, Drochioiu G, Vasilache V, Sandu I. The influence of dinitrophenolic pesticides on the viability of plants. Rev Chim. 2015;66(9):1321-6.

24. Pintilie O, Ion L, Surleva A, Zaharia M, Todirascu-Ciornea E, Ciubotariu E, Balan A, Drochioiu G, Sandu I. Monitoring methods of plant viability in genetic conservation. Rev Chim. 2016;67(4):687-91.

25. Briat JF, Fobis-Loisy I, Grignon N, Lobréaux S, Pascal N, Savino G, Thoiron S, Von Wirén N, Van Wuytswinkel O. Cellular and molecular aspects of iron metabolism in plants. Biol Cell. 1995;84(1-2):69-81.

26. Sharma P, Dubey RS. Lead toxicity in plants. Braz J Plant Physiol. 2005;17(1):35-52.

27. Ernst W. Effects of heavy metals in plants at the cellular and organismic levels. In: Schuuurmann G, editor. Ecotoxicology: Ecological Fundamentals, Chemical Exposure and Biological Effects. Heidelberg: Wiley; 1998, p. 587-620.

28. Seregin IV, Ivaniov VB. Physiological aspects of cadmium and lead toxic effects on higher plants. Russ J Plant Physiol. 2001;48:606-30.

29. Østergaard L, Teilum K, Mirza O, Mattsson O, Petersen M, Welinder GK, Mundy J, Gajhede M, Henriksen A. Arabidopsis ATP A2 peroxidase. Expression and high resolution structure of a plant peroxidase with implications for lignification. Plant Mol Biol. 2000;44: 231-43.

30. Passardi F, Cosio C, Penel C, Dunand C. Peroxidases have more functions than a Swiss army knife. Plant Cell Rep. 2005;24:255-65.

31. Marjamaa K, Kukkola ME, Fagerstedt VK. The role of xylem class III peroxidases in lignification. J Exp Bot. 2008;60(2):367-76.

32. Díaz-Tiaels C, Graña E, Reigosa JM, Sánchez-Moreiras MA. The role of peroxidases on the mode of action of chalcone in Arabidopsis roots. Plant Signal Behav. 2012;7(10):1274-6.

33. Todiraşcu-Ciornea E, Drochioiu G, Ştefănescu R, Axinte EV, Dumitru G. Morphological and biochemical answer of the wheat seeds at treatment with 2,4-dinitrophenol and potassium iodate. Braz Arch Biol Technol. 2016;59:e16150580. doi:10.1590/1678-4324-2016150580.

34. Schopfer P. Hydroxyl radical-induced cell-wall loosening in vitro and in vivo: implications for the control of elongation growth. The Plant Journal. 2001;28(6): 679-88.

35. Kawano $T$. Roles of the reactive oxygen species- generating peroxidase reactions in plant defence and growth induction. Plant Cell Rep. 2003;21(9):829-37.

36. Zhang Y, Chen B, Xu Z, Shi Z, Chen S, Huang X, Chen J, Wang X. Involvement of reactive oxygen species in endosperm cap weakening and embryo elongation growth during lettuce seed germination. J Exp Bot. 2014. doi:10.1093/jxb/eru167.

37. Wei-Ching F, Ching Huei K. Enhanced peroxidase activity in rice leaves in response to excess iron, copper and zinc. Plant Sci. 2000;158:71-6.

38. Sinha S, Saxena R. Effect of iron on lipid peroxidation, and enzymatic and non-enzymatic antioxidants and bacoside - A content in medicinal plant Bacopa monnieri L. Chemosphere. 2006;62:1340-50.

39. Pooladvand S, Ghorbanli M, Sepehr MF. Effect of various levels of iron on morphological, biochemical, and physiological properties of Glycine max var. Pershing. Iranian Journal of Plant Physiology. 2012;2(4):531-8.

40. Sun B, Jing Y, Chen L, Song F, Chen L, Zhang L. Protective effect of nitric oxide on iron deficiency-induced oxidative stress in maize (Zea mays). J Plant Physiol. 2007;164:536-43. 
41. Ranieri A, Castagna A, Baldan B, Soldatini GF. Iron deficiency differently affects peroxidase isoforms in sunflower. J Exp Bot. 2001;52(354):25-35.

42. Ravikumar S, Thamizhiniyzn P. Impact of lead on growth, bio chemical and enzymatic changes in black gram. Int Res J Pharm App Sci. 2014;4(4):1-3.

43. Verma S, Dubey RS. Lead toxicity induces lipid peroxidation and alters the activities of antioxidant enzymes in growing rice plants. Plant Sci. 2003;164:645-55.

44. Del Rio LA, Sandalio LM, Corpas FJ, Romero-Puertas MC, Palma JM. Peroxisome as a acellular source of ROS signal molecules. In: Del Rio LA, Puppo A, editors. Reactive oxygen species in plant signaling. Springer; 2009, p. 100-102.

45. Vara Prasad MN, De Oliveira Freitas HM. Metal hyperaccumulation in plants - Biodiversity prospecting for phytoremediation technology. Electron J Biotechn. 2003;6(3):285-305.

46. Bai XY, Dong YJ, Wang QH, Xu LL, Kong J, Liu S. Effects of lead and nitric oxide on photosynthesis, antioxidative ability, and mineral element content of perennial ryegrass. Biol Plantarum. 2015;59(1):163-70.

47. Dias MC. Phytotoxicity: An overview of the physiological responses of plants exposed to fungicides. Journal of Botany. 2012;135479. doi:10.1155/2012/135479.

48. Abdel Latef AA. Growth and some physiological activities of pepper (Capsicum annuum L.) in response to cadmium stress and mycorrhizal symbiosis. J Agr Sci Tech. 2013;15:1437-48.

49. Malar S, Vikram SS, Favas PJC, Perumal V. Lead heavy metal toxicity induced changes on growth and antioxidative enzymes level in water hyacinths [Eichhornia crassipes (Mart.)]. Bot Stud. 2014;55(54).

50. Pierre Vitória A, Lage-Pinto F, Campaneli Da Silva LB, Da Cunha M, De Oliveira JG, Rezende CE, De Souza CMM, Azevedo RA. Structural and ecophysiological alterations of the water hyacinth [Eichhornia crassipes (Mart.) Solms] due to anthropogenic stress in brazilian rivers. Braz Arch Biol Technol. 2011;54(5):1059-68.

51. Piotrowska A, Bajguz A, Godlewska B, Czerpak R, Kaminska M. Jasmonic acid as modulator of lead toxicity in aquatic plant Wolffia arrhiza (Lamnaceae). Environ Exp Bot. 2009;66:507-13.

52. Singh R, Tripathi RD, Dwivedi S, Kumar A, Trivedi PK, Chakrabarty D. Lead bioaccumulation potential of an aquatic macropyte Najas indica are related to antioxidant system. Bioresour Technol. 2010;101:3025-32.

53. Hernández-Bautista L, Trejo-Téllez LI, Gómez-Merino FC, García-Morales S, Tejeda-Sartorius O. Physiological and nutrient changes in sweet pepper (Capsicum annuum L.) seedlings caused by cadmium. Rev Int Contam Ambie. 2015;31(4):389-96.

54. Hejtmánková K, Kotíková Z, Hamouz K, Pivec V, Vacek J, Lachman J. Influence of flesh colour, year and growing area on carotenoid and anthocyanin content in potato tubers. J Food Compos Anal. 2013;32:20-7.

55. Valcarcel J, Reilly K, Gaffney M, O'brien N. Total carrotenoids and L-ascorbic acid content in 60 varieties of potato (Solanum tuberosum L.) grown in Ireland. Potato Res. 2015;58:29-41.

56. Hamouz K, Pazderů K, Lachman J, Čepl J, Kotíková Z. Effect of cultivar, flesh colour, locality and year on carotenoid content in potato tubers. Plant Soil Environ. 2016;62(2):86-91.

(c) 2018 by the authors. Submitted for possible open access publication under the terms and conditions of the Creative Commons Attribution (CC BY NC) license (https://creativecommons.org/licenses/by-nc/4.0/). 